\title{
How to design psychiatric facilities to foster positive social interaction - A systematic review
}

\author{
Nikolina Jovanovića, ${ }^{a}$, Justin Campbell ${ }^{\mathrm{b}}$, Stefan Priebe ${ }^{\mathrm{a}}$ \\ a Unit for Social and Community Psychiatry, WHO Collaborative Centre for Mental Health Services Development, Blizard Institute, Bart's and London School of \\ Medicine and Dentistry, Queen Mary University of London, United Kingdom \\ ${ }^{\mathrm{b}}$ Institute for Global Health, University College London, United Kingdom
}

\section{A R T I C L E I N F O}

\section{Article history:}

Received 10 December 2018

Received in revised form 17 April 2019

Accepted 18 April 2019

Available online 18 May 2019

\section{Keywords:}

Psychiatric hospital

Facility

Social interaction

Architecture

Design

Review

\begin{abstract}
A B S T R A C T
Psychiatric facilities are often criticised of being poorly designed which may contribute to violent incidents and patients' complaints of feeling bored and lacking meaningful interactions with peers and staff. There is a lack of understanding how to design environments for staff, patients and visitors to engage in positive social interactions (e.g. conversation, sharing, peer support). We conducted a systematic literature review on which architectural typologies and design solutions facilitate helpful social interactions between users of psychiatric facilities. Several interventions were identified such as choosing a community location; building smaller (up to 20 beds) homelike and well integrated facilities with single/double bedrooms and wide range of communal areas; provision of open nursing stations; ensuring good balance between private and shared spaces for patients and staff; and specific interior design interventions such as arranging furniture in small, flexible groupings, introduction of plants on wards, and installing private conversation booths. These interventions range from simple and non-costly to very complex ones. The evidence should inform the design of new hospitals and the retrofitting of existing ones.
\end{abstract}

(c) 2019 Published by Elsevier Masson SAS.

\section{Introduction}

The design of psychiatric facilities has always reflected dominant social views about mental illness. The de-institutionalisation of services in the 1960s has shifted the purpose of psychiatric treatment from containment to recovery, thus proposing the transition from traditional hospital-based care to care focused on supporting and maintaining patients within their homes and communities [1]. Within this shift, psychiatric inpatient services should have abandoned the culture of paternalism and embraced the new way of working which allows patients to make informed decisions about their care and treatment, in partnership with their health and social care practitioners. One of the tasks of psychiatric treatment should be to create a safe environment for people to try out positive social interactions (e.g. sharing, peer support, and positive feedback) [2]. However, psychiatric facilities are still criticised for being designed as

\footnotetext{
* Corresponding author at: Unit for Social and Community Psychiatry, WHO Collaborative Centre for Mental Health Services Development, Bart's and London School of Medicine and Dentistry, Queen Mary University of London, NCfMH, Glen Road, London, E13 8SP, United Kingdom.

E-mail address: n.jovanovic@qmul.ac.uk (N. Jovanović).
}

custodial and repressive [3,4]. Patients treated in psychiatric facilities have repeatedly complained of experiencing negative interactions (e.g. violence), boredom, and of a lack of meaningful interactions with peers, staff and family members [5-8].

Increasingly, the architecture of psychiatric facilities, including the internal and external environments has been shown to influence the way in which healthcare is delivered. The healthcare delivery is also influenced by other factors such as cultural attitudes and assumptions of the wider society within which the facility is located as well as staff attitudes to the management of psychiatric patients. The term 'therapeutic milieu' has been used to describe the physical, social, and cultural context of providing psychiatric care in a holistic manner that supports positive health outcomes [8]. Just as psychiatry has moved toward an evidencebased approach, so too should the design of psychiatric facilities be informed by the best available evidence in order to demonstrate improvements in clinical outcomes, economic performance, and users' satisfaction [9-11]. However, the link between psychiatric facilities and clinical outcomes of patients can be very complex. A model is therefore required to search and understand the evidence. The theoretical framework for this study is based on Ulrich's theory of supportive design [12]. According to this theory, the hospital environment will reduce stress in patients if it provides opportunities for social interaction, fosters patients' perceptions 
of control and autonomy, and creates positive distractions. With regard to social interaction, both the receipt and provision of social support have been found to have beneficial effects. For example, family presence in healthcare settings or genuine peer support is believed to enhance health outcomes and the patient experience. There is strong evidence from early studies conducted during 1970 s and 1980s that levels of social interaction can be increasedand presumably beneficial social support as well-by providing communal areas with comfortable movable furniture arranged in small flexible groupings. These studies have largely been conducted in psychiatric units and nursing homes [11]. In this review we wanted to further explore more recent literature in this field. One may assume that buildings can foster or hinder relevant interactions between users which may then influence outcomes, so that positive social interaction can be taken as a key behavioural criterion to assess the role of architecture. We therefore conducted a systematic review of the existing evidence on the relationship between design and social interactions between different users of psychiatric facilities. Since such evidence cannot always be based on randomised-controlled trials, a wider approach with a narrative synthesis has been taken. We used 'psychiatric facility' as a general term for psychiatric in-patient facilities and residential community facilities used by psychiatric patients.

\section{Methods}

The review followed the Preferred Reporting Items for Systematic reviews and Meta-Analyses (PRISMA) statement [13]. The protocol was published on PROSPERO on 1 June 2015 (https:// www.crd.york.ac.uk/prospero/display_record.php?

RecordID=22074). Six electronic databases (PubMed, EMBASE, PsycINFO, CINAHL, Scopus, Web of Science) were searched from their inception to December 2018. The search words included 'psychiatric hospitals' [MeSH], 'psychiatric ward', 'psychiatric facility', 'built environment' [MeSH], 'architecture' [MeSH], 'design', 'social interaction', 'interpersonal relationships'[MeSH], and 'social support'. The reference lists of all included articles were hand searched for potentially relevant articles.

\subsection{Eligibility criteria}

Studies were included if a) conducted in psychiatric facilities with adults (age 18-65), b) reported at least one measure/ description of design, and c) reported at least one measure of social interactions. No restriction was placed on location, language, or year of publication. The measures of design were related to urban planning and architecture (e.g. site/location and relatively permanent characteristics such as spatial layout of a hospital, room size, window placement), interior design (e.g. less permanent elements such as furnishings, colours, artwork), and ambient features (e.g. lightning, noise levels, temperature, and odours) [14]. Social interaction was defined as a process whereby people engage one another in mutually responsive ways. Because the terminology is inconsistent, we used the following descriptors: social interaction, social support, communication, social relationships, personal relationships, social capital, and family support. Studies that reported on structural (frequency or size) and/or functional (quality) dimensions of social interaction were included. We included studies reporting on positive (e.g. staff-patient conversations) and/or negative interactions (e.g. violent incidents).

\subsection{Study selection, data extraction and quality assessment}

All potential studies were exported into reference management software. After removing duplicates, the first author (NJ) screened all titles and abstracts while the other author (JC) screened a random selection of $20 \%$ of titles and abstracts to ensure the consistency. If there was any ambiguity on the eligibility of the study, the full paper was reviewed between the two authors (NJ and JC). Inter-reviewer agreement was $90 \%$. The full text of articles

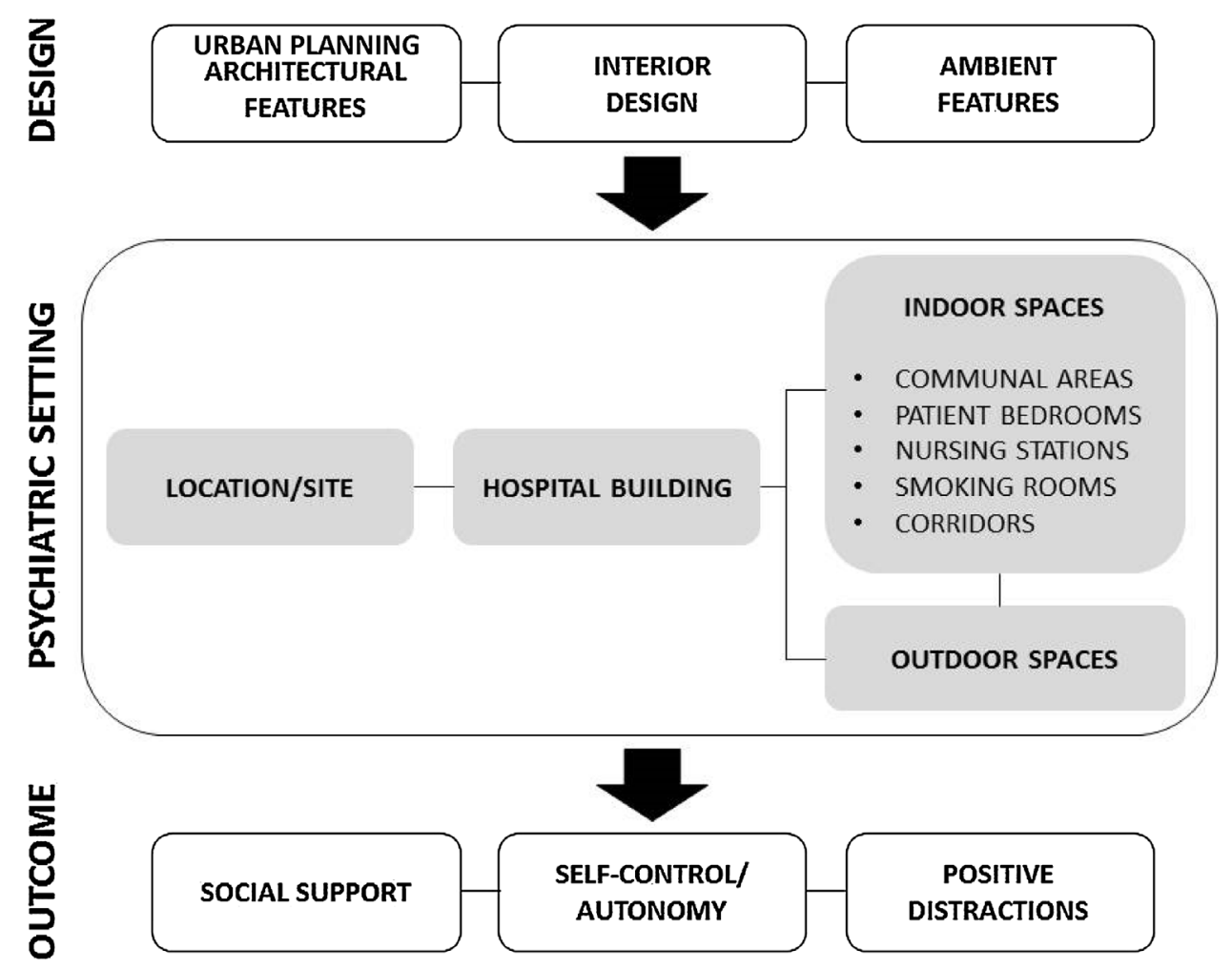

Fig. 1. Theoretical framework. 


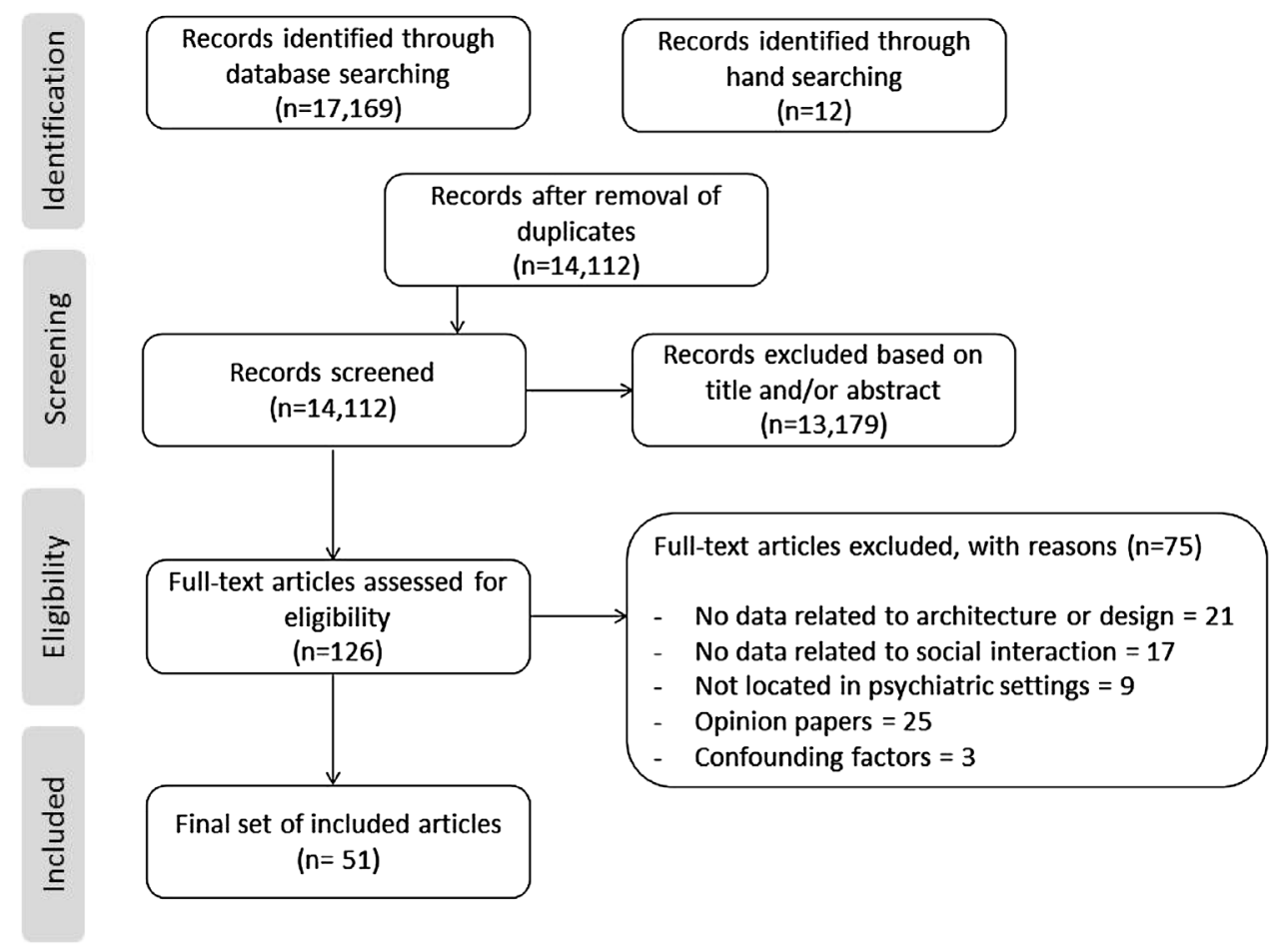

Fig. 2. Study selection.

meeting the criteria were obtained and reviewed. Reasons for exclusion were recorded. Data extraction was completed independently by two reviewers (NJ and JC). Data were extracted on study methodology, patient characteristics, design characteristics, and social interaction. Study quality was assessed using The Quality Assessment Tool for Quantitative Studies [15] and the RATS for qualitative studies [16]. The Quality Assessment Tool for Quantitative Studies leads to an overall methodological rating of strong, moderate, or weak in eight sections: selection bias; study design; confounders; blinding; data collection methods; withdrawals and dropouts; intervention integrity; and analysis. The RATS has been used to assess four key areas such as relevance of study question; appropriateness of qualitative method; transparency of procedures; and soundness of interpretive approach.

\subsection{Data analysis}

Narrative synthesis was used to analyse the data, which included four components: theory development, preliminary synthesis, exploring relationships within and between studies, and assessing robustness of synthesis [17]. These elements were undertaken sequentially in an iterative process throughout the review cycle. The theoretical framework includes design interventions (urban planning/architectural/interior design/ambient features) applied at different levels (e.g. from choosing the right building location to designing interior and exterior spaces) in order to create a functional and socially supportive facility [12,14,18,19]. Please see Fig. 1.

Tabulation and grouping data were used to create a preliminary synthesis of how the hospital design encourages social interactions between patients, staff, and visitors. The initial synthesis was largely based on data from randomised-controlled and casecontrolled studies. The synthesis was shared among the study authors for discussion and refinement [17].

\section{Results}

The selection procedure is displayed in Fig. 2. The final selection consists of 51 studies including 33 interventional studies in which interventions ranged from moving into a new facility $(\mathrm{N}=15)$ to ward redesign $(\mathrm{N}=10)$ to $\operatorname{room}(\mathrm{s})$ redesign $(\mathrm{N}=8)$. Three interventional studies were randomised-controlled trials and others used pre-post evaluation. The rest of the included studies were observational in nature $(\mathrm{N}=18)$, conducted in a single setting $(\mathrm{N}=6)$ or across two or more settings $(\mathrm{N}=12)$. Three studies were reported in two separate papers and one study was reported in three separate papers. The studies were published between 19682018, deriving from eight countries: United States $(N=21)$, United Kingdom $(\mathrm{N}=14)$, Canada $(\mathrm{N}=5)$, Australia $(\mathrm{N}=4)$, Sweden $(\mathrm{N}=2)$, Norway $(\mathrm{N}=1)$, Germany $(\mathrm{N}=2)$, and Netherland $(\mathrm{N}=2)$. Details are listed in Table 1.

\subsection{Location of psychiatric facilities}

Building psychiatric facilities within local communities rather than in isolated locations has three main advantages: it encourages patients to spend more time in the community [20-23], enables families to regularly visit patients, and reduces stigma [24,25]. Two studies have shown that once barriers of distance are removed, most psychiatric patients used ordinary community resources for their needs [21,24]. That in itself was not enough to enable patients to make new friends or renew family relationships. The architectural interventions, such as physical overlapping or integration of territories identified with various categories of users can facilitate their interactions [20]. For example, public areas can be included in the care spaces with amenities and equipment that can also be used by local residents $[5,20,26]$. 
Table 1

Study characteristics, level of design intervention, psychiatric setting and outcomes.

\begin{tabular}{|c|c|c|c|c|c|c|c|}
\hline Publication & Country & Type of study & Participants & $\begin{array}{l}\text { Design } \\
\text { intervention }\end{array}$ & $\begin{array}{l}\text { Psychiatric } \\
\text { facility }\end{array}$ & Outcome & $\begin{array}{l}\text { Quality } \\
\text { rating }\end{array}$ \\
\hline \multicolumn{8}{|c|}{ QUANTITATIVE STUDIES } \\
\hline \multicolumn{8}{|c|}{ Randomised controlled studies } \\
\hline $\begin{array}{l}\text { Holahan } \\
(1972)\end{array}$ & USA & $\begin{array}{l}\text { Randomized- } \\
\text { controlled } \\
\text { study }\end{array}$ & $\begin{array}{l}120 \text { male psychiatric } \\
\text { inpatients }\end{array}$ & $\begin{array}{l}\text { Interior } \\
\text { design }\end{array}$ & Communal area & $\begin{array}{l}\text { Sociopetal (chairs arranged around two } \\
\text { small tables in the middle of the room) and } \\
\text { mixed settings were significantly more } \\
\text { social than the sociofugal (chairs arranged } \\
\text { shoulder to shoulder along the walls of the } \\
\text { room) and free settings. }\end{array}$ & Moderate \\
\hline $\begin{array}{l}\text { Holahan \& } \\
\text { Saegert } \\
\text { (1973), } \\
\text { Holahan } \\
(1976)\end{array}$ & USA & $\begin{array}{l}\text { Randomized- } \\
\text { controlled } \\
\text { study }\end{array}$ & $\begin{array}{l}50 \text { psychiatric inpatients, } \\
\text { mixed gender, 50\% with } \\
\text { psychosis }\end{array}$ & $\begin{array}{l}\text { Interior } \\
\text { design }\end{array}$ & Inpatient ward & $\begin{array}{l}\text { The remodelled ward (repainted, new } \\
\text { furniture and changes to increase a range of } \\
\text { social options: six-foot-high partitions, } \\
\text { two-bed sections in each dormitory, a table } \\
\text { and two comfortable chairs in each } \\
\text { bedroom to allow for private conversation) } \\
\text { was characterized by increased interaction } \\
\text { among patients, staff, and visitors and } \\
\text { decreased isolated passive behaviour. The } \\
\text { arrangement of new tables and chairs in } \\
\text { one dayroom encouraged small group } \\
\text { interaction while a second dayroom's } \\
\text { arrangement facilitated watching TV or } \\
\text { playing games. Larger group socializing } \\
\text { occurred at large tables in the dining room. } \\
\text { No difference was found in isolated active } \\
\text { behaviour (walking, reading). }\end{array}$ & Moderate \\
\hline $\begin{array}{l}\text { Davidson } \\
(1996)\end{array}$ & USA & $\begin{array}{l}\text { Randomized- } \\
\text { controlled } \\
\text { study }\end{array}$ & 35 patients, 4 staff & $\begin{array}{l}\text { Interior } \\
\text { design }\end{array}$ & $\begin{array}{l}\text { Inpatient unit } \\
\text { Community } \\
\text { facility }\end{array}$ & $\begin{array}{l}\text { The inpatient setting offered more social } \\
\text { and recreational aids which encouraged } \\
\text { more social activity within the unit. } \\
\text { However, the patients in the community } \\
\text { facility were more socially active outside } \\
\text { the facility. }\end{array}$ & Moderate \\
\hline \multicolumn{8}{|c|}{ Non-randomised controlled studies } \\
\hline $\begin{array}{l}\text { Wykes } \\
\text { (1982) }\end{array}$ & UK & $\begin{array}{l}\text { Observational } \\
\text { study with } \\
\text { controlled } \\
\text { group }\end{array}$ & $\begin{array}{l}25 \text { long-stay psychiatric } \\
\text { patients }\end{array}$ & $\begin{array}{l}\text { Architectural } \\
\text { features } \\
\text { Interior } \\
\text { design }\end{array}$ & $\begin{array}{l}\text { Community } \\
\text { facility }\end{array}$ & $\begin{array}{l}\text { The design of a hospital-ward (traditional } \\
\text { institutional designs, large living areas) had } \\
\text { less social activities than the design of a } \\
\text { hostel-ward (homelike features, living } \\
\text { areas, double bedrooms, bright colours, } \\
\text { good quality furniture, and the ability for } \\
\text { patients to decorate their rooms). }\end{array}$ & Moderate \\
\hline $\begin{array}{l}\text { Whitehead } \\
\text { (1984) }\end{array}$ & USA & $\begin{array}{l}\text { Experimental, } \\
\text { case-control } \\
\text { study }\end{array}$ & $\begin{array}{l}30 \text { male and female } \\
\text { psychiatric inpatients }\end{array}$ & $\begin{array}{l}\text { Architectural } \\
\text { features } \\
\text { Interior } \\
\text { design }\end{array}$ & $\begin{array}{l}\text { Inpatient ward } \\
\text { Nursing station }\end{array}$ & $\begin{array}{l}\text { The redesigned ward increased social } \\
\text { interaction via breaks up long institutional } \\
\text { corridors subdivides dormitories, improves } \\
\text { access to visiting room, adds flexibility of } \\
\text { use to group and day rooms, opens the } \\
\text { nursing station and accentuates practical } \\
\text { purposes and humanistic values through } \\
\text { colour and graphics and attractive } \\
\text { furnishings. There was no significant } \\
\text { impact on length of stay in the new ward. }\end{array}$ & Moderate \\
\hline $\begin{array}{l}\text { Christenfeld } \\
\text { (1989) }\end{array}$ & USA & $\begin{array}{l}\text { Pre-post } \\
\text { renovation } \\
\text { controlled } \\
\text { study }\end{array}$ & $\begin{array}{l}81 \text { patients with } \\
\text { schizophrenia, } 71 \text { staff }\end{array}$ & $\begin{array}{l}\text { Interior } \\
\text { design }\end{array}$ & Inpatient ward & $\begin{array}{l}\text { Adding a series of waist-high walls } \\
\text { throughout a ward's large dayroom } \\
\text { promoted conversations and allowed } \\
\text { places where a patient can be alone. The } \\
\text { rate of patient violence decreased almost } \\
50 \% \text {. No improvement in perceived social } \\
\text { isolation was detected. }\end{array}$ & Moderate \\
\hline $\begin{array}{l}\text { Devlin } \\
\quad(1992)\end{array}$ & USA & $\begin{array}{l}\text { Pre-post } \\
\text { renovation } \\
\text { controlled } \\
\text { study }\end{array}$ & 82 inpatients, 83 staff & $\begin{array}{l}\text { Interior } \\
\text { design } \\
\text { Ambient } \\
\text { eatures }\end{array}$ & Inpatient wards & $\begin{array}{l}\text { New furnishings and the introduction of } \\
\text { plants improved staff assessment of the } \\
\text { environment and reduced patients' } \\
\text { stereotypy. The most uniformly positive } \\
\text { addition to the wards was the plants, and } \\
\text { the major comment was that even more } \\
\text { were needed. Changes in paint, colour, and } \\
\text { lightning had no effect. }\end{array}$ & Moderate \\
\hline $\begin{array}{l}\text { Eggert } \\
\qquad(2014) \\
\text { Dvoskin } \\
(2002)\end{array}$ & USA & $\begin{array}{l}\text { Pre-post } \\
\text { occupation } \\
\text { controlled } \\
\text { study }\end{array}$ & $\begin{array}{l}526 \text { forensic inpatients, } \\
353 \text { staff }\end{array}$ & $\begin{array}{l}\text { Architectural } \\
\text { features }\end{array}$ & Outdoor space & $\begin{array}{l}\text { The addition of small quiet gathering } \\
\text { spaces in each of the residential wings, } \\
\text { open-air courtyards, and day halls with } \\
\text { notably more floor space and abundant } \\
\text { natural light allowed the patients more } \\
\text { room to separate themselves from } \\
\text { problematic interactions. These additional } \\
\text { choices increased perceptions of safety, } \\
\text { cohesion and mutual social support. The } \\
\text { number of seclusions and restraint }\end{array}$ & Moderate \\
\hline
\end{tabular}


Table 1 (Continued)

\begin{tabular}{|c|c|c|c|c|c|c|c|}
\hline Publication & Country & Type of study & Participants & $\begin{array}{l}\text { Design } \\
\text { intervention }\end{array}$ & $\begin{array}{l}\text { Psychiatric } \\
\text { facility }\end{array}$ & Outcome & $\begin{array}{l}\text { Quality } \\
\text { rating }\end{array}$ \\
\hline Ulrich (2018) & Sweden & $\begin{array}{l}\text { Pre-post } \\
\text { relocation } \\
\text { controlled } \\
\text { study }\end{array}$ & 42 psychiatric patients & $\begin{array}{l}\text { Architectural } \\
\text { features } \\
\text { Interior } \\
\text { design }\end{array}$ & Inpatient ward & $\begin{array}{l}\text { episodes and patient-to-patient and } \\
\text { patient-to-staff assaults found no change. } \\
\text { Compared to the old hospital, the new } \\
\text { wards were characterised with lower social } \\
\text { density (number of person per room) and } \\
\text { more stress-reducing features (e.g. more } \\
\text { single bedrooms with private bathrooms, } \\
\text { communal areas with movable seating, } \\
\text { noise reduction design, design to foster } \\
\text { control in patient rooms, garden accessible } \\
\text { to patient, design for higher daylight } \\
\text { exposure, and communal spaces and } \\
\text { bedroom doors observable from central } \\
\text { area). The proportion of patients requiring } \\
\text { compulsory injections declined in the new } \\
\text { hospital compared to the old facility but did } \\
\text { not change in the control hospital. }\end{array}$ & Moderate \\
\hline
\end{tabular}

\begin{tabular}{|c|c|c|}
\hline spectiv & ohort & \\
\hline $\begin{array}{l}\text { Edwards \& } \\
\text { Hults }\end{array}$ & USA & $\begin{array}{l}\text { Pre-post } \\
\text { intervention }\end{array}$ \\
\hline
\end{tabular}

80 male psychiatric Interior

inpatients $(75 \%$ with long- design

termschizophrenia) and

21 staff

Nursing stations

\section{nu} staff spent less time in the with patients, patients visited the nursing station less often, the number of patients initiated interactions increased significantly, and indirect nonverbal communication between staff and patients changed to direct, verbal communication. Altogether $84 \%$ of staff and $88 \%$ of patients preferred open nursing station. The intervention decreased ideas of reference among patients.

\begin{tabular}{|c|c|c|c|c|c|}
\hline $\begin{array}{r}\text { Baldwin } \\
(1985)\end{array}$ & UK & $\begin{array}{l}\text { Experimental, } \\
\text { case-control }\end{array}$ & $\begin{array}{l}200 \text { psychiatric inpatients } \\
\text { and } 60 \text { staff }\end{array}$ & $\begin{array}{l}\text { Interior } \\
\text { design }\end{array}$ & $\begin{array}{l}\text { Inpatient ward } \\
\text { Communal area }\end{array}$ \\
\hline Corey (1986) & USA & $\begin{array}{l}\text { Pre-post } \\
\text { renovation }\end{array}$ & $\begin{array}{l}66 \text { psychiatric inpatients } \\
\text { and } 65 \text { staff }\end{array}$ & $\begin{array}{l}\text { Interior } \\
\text { design }\end{array}$ & Inpatient ward \\
\hline $\begin{array}{l}\text { Muller } \\
\text { (1996) }\end{array}$ & Germany & $\begin{array}{l}\text { Pre-post } \\
\text { renovation }\end{array}$ & $\begin{array}{l}55 \text { female psychiatric } \\
\text { inpatients }\end{array}$ & $\begin{array}{l}\text { Architectural } \\
\text { features } \\
\text { Interior } \\
\text { design }\end{array}$ & $\begin{array}{l}\text { Inpatient ward } \\
\text { Communal areas }\end{array}$ \\
\hline
\end{tabular}

$\begin{array}{lll}\text { Tyson (2002) Australia } & \begin{array}{l}\text { Pre-post } \\ \text { renovation }\end{array}\end{array}$

Architectural Inpatient ward features Communal areas Nursing station

Ward furniture arranged into three or more Moderate chairs facing a table with games and books placed on tables improved the social interaction of patients. Non-significant decrease in violence and seclusion rates. The renovation (enlarged colour scheme, wall pictures, new furniture in a conversational arrangement, individual bedside dressers and bookshelves) did not change perceived social support on psychiatric wards. A smaller number of patients per room, Moderate better furniture, and more than one communal room increased the number of patients coming to the dayroom (35\% vs. $64 \%$ ), but they engaged significantly less in conversations with each other (46\% vs. 16 $\%)$.

The addition of the new wards with multibed rooms, shared spaces that included a fully utilised dining room, sitting/TV room, activity room, and external area with outdoor furniture increased positive staff-patients interactions as opposed to the old wards. New wards provided more private areas for nurses and more space for one-to-one interactions was beneficial as nurses spent less time in nursing stations. Interior design Ambient features long-stay facility

After the move from a temporary, refurbished medical ward to a large, lightfilled, purpose-built facility, there was a significant reduction in the number of seclusion episodes. In the new facility, patients were transferred from four patients per bedroom to individual bedrooms and there were large expansions in indoor and outdoor recreational areas. There were statistically significant increases in ambient light conditions in the new unit.

\begin{tabular}{|c|c|c|}
\hline $\begin{array}{c}\text { Borckardt } \\
\text { (2011) }\end{array}$ & USA & $\begin{array}{l}\text { Pre-post } \\
\text { intervention }\end{array}$ \\
\hline
\end{tabular}

5 inpatient units at one psychiatric hospital, 3 adult units, 1 geriatric and 1 child and adolescent unit
Interior design
Inpatient ward
Inexpensive physical changes (e.g. repainting walls with warm colours, placement of decorative throw rugs and plants, rearrangement of furniture to 
Table 1 (Continued)

\begin{tabular}{|c|c|c|c|c|c|c|c|}
\hline Publication & Country & Type of study & Participants & $\begin{array}{l}\text { Design } \\
\text { intervention }\end{array}$ & $\begin{array}{l}\text { Psychiatric } \\
\text { facility }\end{array}$ & Outcome & $\begin{array}{l}\text { Quality } \\
\text { rating }\end{array}$ \\
\hline & & & & & & $\begin{array}{l}\text { facilitate increased patient-patient and } \\
\text { patient-staff interaction, replacing worn- } \\
\text { out furniture) were associated with } \\
\text { significant reduction in rate of seclusion } \\
\text { and restraint. }\end{array}$ & \\
\hline Long (2011) & UK & $\begin{array}{l}\text { Pre-post } \\
\text { relocation } \\
\text { study }\end{array}$ & $\begin{array}{l}9 \text { forensic patients with } \\
\text { personality disorder and } \\
\text { schizoaffective disorder, } \\
16 \text { staff. }\end{array}$ & $\begin{array}{l}\text { Architectural } \\
\text { features }\end{array}$ & Inpatient unit & $\begin{array}{l}\text { The move from an old Victorian hospital to } \\
\text { new, purpose built facility led to no } \\
\text { difference in perceived social support } \\
\text { among users. In contrast to the old ward, } \\
\text { the new unit has an increased amount of } \\
\text { space per head, an enclosed courtyard with } \\
\text { flowerbeds and running water, large } \\
\text { communal area, en suite toilet facilities, } \\
\text { food freshly prepared on site and a view } \\
\text { from each bedroom of nature. }\end{array}$ & Moderate \\
\hline $\begin{array}{l}\text { Urbanoski } \\
\text { (2013) }\end{array}$ & Canada & $\begin{array}{l}\text { Pre-post } \\
\text { renovation }\end{array}$ & $\begin{array}{l}290 \text { patients with mood } \\
\text { and anxiety disorders }\end{array}$ & $\begin{array}{l}\text { Architectural } \\
\text { features }\end{array}$ & Inpatient ward & $\begin{array}{l}\text { Compared to the old ward (traditional } \\
\text { design), patients on the renovated ward } \\
\text { (patient-centred design, private en-suite } \\
\text { rooms, central common room, private } \\
\text { visitation rooms, and a kitchen area) } \\
\text { perceived a more positive atmosphere } \\
\text { regarding greater peer support and } \\
\text { autonomy and more emphasis on practical } \\
\text { skill development. }\end{array}$ & Moderate \\
\hline $\begin{array}{l}\text { van der } \\
\text { Schaaf } \\
(2013)\end{array}$ & Netherlands & $\begin{array}{l}\text { Observational } \\
\text { study }\end{array}$ & $\begin{array}{l}16 \text { psychiatric hospitals, } \\
199 \text { wards, intensive care, } \\
14834 \text { patients }\end{array}$ & $\begin{array}{l}\text { Architectural } \\
\text { features } \\
\text { Interior } \\
\text { design }\end{array}$ & Inpatient ward & $\begin{array}{l}\text { Architectural features such as more total } \\
\text { private space per patient, a higher level of } \\
\text { comfort and greater visibility on the ward } \\
\text { decreased the risk of being secluded. }\end{array}$ & Moderate \\
\hline $\begin{array}{l}\text { Jenkins } \\
\text { (2014) }\end{array}$ & UK & $\begin{array}{l}\text { Pre-post } \\
\text { relocation }\end{array}$ & $\begin{array}{l}18 \text { patients, mostly male, } \\
\text { F2 spectrum }\end{array}$ & $\begin{array}{l}\text { Architectural } \\
\text { features }\end{array}$ & $\begin{array}{l}\text { Inpatient ward, } \\
\text { intensive care } \\
\text { unit }\end{array}$ & $\begin{array}{l}\text { The move from an old, temporary building } \\
\text { to a new, purpose-built ward led to } \\
\text { decrease in aggressive incidents and } \\
\text { seclusion. This was associated with greater } \\
\text { space on the new ward which enabled more } \\
\text { privacy and better visibility. }\end{array}$ & Moderate \\
\hline $\begin{array}{l}\text { Dressler } \\
(2015)\end{array}$ & Germany & $\begin{array}{l}\text { Pre-post } \\
\text { relocation }\end{array}$ & 18 psychiatric inpatients & $\begin{array}{l}\text { Architectural } \\
\text { features } \\
\text { Interior } \\
\text { design }\end{array}$ & Inpatient ward & $\begin{array}{l}\text { The new building had substantially } \\
\text { increased ward space, changed room } \\
\text { settings (from mainly 2-4 bed rooms to only } \\
\text { 2- and 1-bed rooms), improved sanitary } \\
\text { arrangement, more natural lighting, } \\
\text { modern home electronics and large } \\
\text { balconies. Service organisation remained } \\
\text { almost the same. Significant reduction in } \\
\text { seclusion and physical or mechanical } \\
\text { restraint in the new building. }\end{array}$ & Moderate \\
\hline $\begin{array}{l}\text { Nicholls } \\
\text { (2015) }\end{array}$ & Australia & $\begin{array}{l}\text { Pre-post } \\
\text { relocation }\end{array}$ & $\begin{array}{l}100 \text { psychiatric acute } \\
\text { inpatients, } 92 \text { staff }\end{array}$ & $\begin{array}{l}\text { Architectural } \\
\text { features }\end{array}$ & Communal areas & $\begin{array}{l}\text { After the move from old (cramped, dark, } \\
\text { few usable outdoor areas, minimal therapy, } \\
\text { and social spaces, shared bedroom and } \\
\text { bathroom facilities) to the new facility } \\
\text { (purpose-built, individual en-suite } \\
\text { bedrooms, recreational courtyards, } \\
\text { increased social and therapy space) } \\
\text { patients perceived themselves as being } \\
\text { more socially active and energetic. }\end{array}$ & Moderate \\
\hline \multicolumn{8}{|c|}{ Cross-sectional studies } \\
\hline $\begin{array}{l}\text { Sommer \& } \\
\text { Gilliland } \\
\text { (1961) }\end{array}$ & Canada & Observational & $\begin{array}{l}\text { Patients and staff from } \\
\text { psychiatric hospital for } \\
1500 \text { patients and } 500 \\
\text { staff }\end{array}$ & $\begin{array}{l}\text { Architectural } \\
\text { features }\end{array}$ & $\begin{array}{l}\text { Inpatient wards } \\
\text { Corridors }\end{array}$ & $\begin{array}{l}\text { Five times as many patients were occupied } \\
\text { constructively in the dayroom than in the } \\
\text { corridor or outside hallway. Patients who } \\
\text { sat in the outside corridor tended to isolate } \\
\text { themselves. They tended to report not } \\
\text { having friends ( } 56 \% \text { compared to } 31 \% \text { in day } \\
\text { room). }\end{array}$ & Moderate \\
\hline $\begin{array}{l}\text { Srivastava \& } \\
\text { Good } \\
(1968)\end{array}$ & USA & $\begin{array}{l}\text { Observational } \\
\text { comparative } \\
\text { study }\end{array}$ & 105 psychiatric patients & $\begin{array}{l}\text { Architectural } \\
\text { features } \\
\text { Interior } \\
\text { design }\end{array}$ & Inpatient wards & $\begin{array}{l}\text { The wards in the nineteenth century } \\
\text { building varied in structural characteristics } \\
\text { (e.g., design complexity; open/glass- } \\
\text { enclosed nursing stations; location, design, } \\
\text { and equipment of communal areas). The } \\
\text { open nursing station areas were focal } \\
\text { points of interaction. Occupational therapy } \\
\text { rooms were favourite spots for large } \\
\text { groups. The location of communal areas at } \\
\text { opposite ends contributed to the } \\
\text { decentralisation of groups and activation of } \\
\text { connecting corridors. Groups commonly } \\
\text { tended to form near windows and } \\
\text { congregated around low partitions }\end{array}$ & Moderate \\
\hline
\end{tabular}


Table 1 (Continued)

\begin{tabular}{|c|c|c|c|c|c|c|c|}
\hline Publication & Country & Type of study & Participants & $\begin{array}{l}\text { Design } \\
\text { intervention }\end{array}$ & $\begin{array}{l}\text { Psychiatric } \\
\text { facility }\end{array}$ & Outcome & $\begin{array}{l}\text { Quality } \\
\text { rating }\end{array}$ \\
\hline $\begin{array}{l}\text { Ittelson } \\
\quad(1970)\end{array}$ & USA & $\begin{array}{l}\text { Observational } \\
\text { comparative } \\
\text { study }\end{array}$ & $\begin{array}{l}75 \text { acute psychiatric } \\
\text { inpatients, } 40 \text { long-term } \\
\text { patients }\end{array}$ & $\begin{array}{l}\text { Architectural } \\
\text { features } \\
\text { Interior } \\
\text { design }\end{array}$ & $\begin{array}{l}\text { Psychiatric } \\
\text { hospital } \\
\text { Communal areas } \\
\text { Patients' } \\
\text { bedrooms }\end{array}$ & $\begin{array}{l}\text { ( } \leq 1,2 \mathrm{~m} \text { ) which were also influenced by } \\
\text { seating arrangements. } \\
\text { Single or double rooms are characterised } \\
\text { with more social activity. Dormitory rooms } \\
\text { are characterised with more isolated } \\
\text { passive behaviour (e.g. lying on a bed) and } \\
\text { lower occupancy rates. Women found to } \\
\text { require more privacy. }\end{array}$ & Moderate \\
\hline $\begin{array}{l}\text { Fairbanks } \\
\text { (1977) }\end{array}$ & USA & Observational & $\begin{array}{l}\text { Total number of patients } \\
\text { and staff ranged from } 1,115 \\
\text { to } 1,274\end{array}$ & $\begin{array}{l}\text { Architectural } \\
\text { features } \\
\text { Interior } \\
\text { design }\end{array}$ & $\begin{array}{l}\text { Inpatient wards } \\
\text { Communal areas }\end{array}$ & $\begin{array}{l}\text { The addition of social areas increased social } \\
\text { interaction in these areas, but at the } \\
\text { expense of a decrease in interaction in } \\
\text { other rooms, thus resulting in no significant } \\
\text { difference between the two wards in the } \\
\text { total frequency of social behaviour. }\end{array}$ & Moderate \\
\hline $\begin{array}{l}\text { Polsky \& } \\
\text { Chance } \\
\text { (1980) }\end{array}$ & UK & Experimental & $\begin{array}{l}24 \text { male inpatients with } \\
\text { long-term schizophrenia, } \\
8 \text { staff }\end{array}$ & $\begin{array}{l}\text { Interior } \\
\text { design }\end{array}$ & Communal areas & $\begin{array}{l}\text { The physical appearance of the ward was } \\
\text { pleasant but conservative. Patients who } \\
\text { interacted the most tended to sit in the } \\
\text { areas closest to the front of the ward } \\
\text { (entrance, nursing station, toilets, } \\
\text { kitchenette, and access to other parts of the } \\
\text { ward). Middle interactors preferred the } \\
\text { areas furthest from the front. The back parts } \\
\text { of the wards encouraged socially } \\
\text { withdrawn patients to avoid social } \\
\text { interaction. }\end{array}$ & Moderate \\
\hline Rice (1980) & USA & Experimental & $\begin{array}{l}14 \text { inpatients with long- } \\
\text { term schizophrenia }\end{array}$ & $\begin{array}{l}\text { Interior } \\
\text { design }\end{array}$ & Dining rooms & $\begin{array}{l}\text { The introduction of flowers into dining } \\
\text { rooms on wards was followed by an } \\
\text { increase in social gazing, time spent in the } \\
\text { dining room, and food consumed. The } \\
\text { introduction of wine bottles led to a } \\
\text { significant increase in vocalisations, social } \\
\text { gazing, time spent in the dining rooms, and } \\
\text { quantity of food consumed. }\end{array}$ & Moderate \\
\hline $\begin{array}{l}\text { Collins } \\
\text { (1985) }\end{array}$ & USA & Observational & $\begin{array}{l}7,971 \text { male psychiatric } \\
\text { inpatients }\end{array}$ & $\begin{array}{l}\text { Interior } \\
\text { design }\end{array}$ & $\begin{array}{l}\text { Inpatient wards } \\
\text { Communal areas }\end{array}$ & $\begin{array}{l}\text { The presence of current magazines on } \\
\text { psychiatric wards was an indicator of } \\
\text { patients' social activity. Furniture grouped } \\
\text { in circles in front of TV was an indicator of } \\
\text { passive social behaviour and poor } \\
\text { therapeutic outcome. }\end{array}$ & Moderate \\
\hline $\begin{array}{l}\text { Gibbons \& } \\
\text { Butler } \\
\text { (1987) }\end{array}$ & UK & Observational & 15 psychiatric patients, & $\begin{array}{l}\text { Architectural } \\
\text { features } \\
\text { Interior } \\
\text { design }\end{array}$ & $\begin{array}{l}\text { Community } \\
\text { facility }\end{array}$ & $\begin{array}{l}\text { The move from hospital to hostel led to } \\
\text { patients spending significantly less time } \\
\text { doing nothing ( } 27 \% \text { vs. 52,5\%), more time } \\
\text { talking ( } 18 \% \text { vs. } 34 \% \text { ) and interacting with } \\
\text { visitors ( } 6 \% \text { vs. } 10 \% \text { ). The hostel residents } \\
\text { visited the community more, and made } \\
\text { more use of its resources, but subjectively } \\
\text { the majority felt lonely and cut off, and } \\
\text { those who lacked contact with relatives and } \\
\text { friends did not increase it after moving. }\end{array}$ & Moderate \\
\hline $\begin{array}{l}\text { Shepherd } \\
\text { (1996) }\end{array}$ & UK & $\begin{array}{l}\text { Observational } \\
\text { comparative }\end{array}$ & $\begin{array}{l}\text { Residents and staff } \\
\text { (numbers not given) from } \\
5 \text { rehabilitation wards and } \\
20 \text { community homes }\end{array}$ & $\begin{array}{l}\text { Architectural } \\
\text { features }\end{array}$ & $\begin{array}{l}\text { Inpatient ward } \\
\text { Community } \\
\text { facility }\end{array}$ & $\begin{array}{l}\text { The most disabled patients were in } \\
\text { hospitals in poor physical environment and } \\
\text { receiving the poorest quality of care. In } \\
\text { hospitals significantly less patient-staff } \\
\text { interactions over } 8 \text { hours were observed } \\
\text { than in community settings (mean } 4.9, \mathrm{SD} \\
2.4 \text { vs mean } 11.1, \text { SD } 4.7 \text { ). Both staff and } \\
\text { residents contributed equally to the } \\
\text { production of positive and negative } \\
\text { interactions, and the highest rates of } \\
\text { negative interactions were seen in hospitals } \\
\text { with the most disabled patients and the } \\
\text { longest serving staff. }\end{array}$ & Moderate \\
\hline $\begin{array}{l}\text { Nijman } \\
\text { (1999) }\end{array}$ & Netherlands & $\begin{array}{l}\text { Observational } \\
\text { comparative } \\
\text { study }\end{array}$ & $\begin{array}{l}354 \text { patients with } \\
\text { substance misuse, mood, } \\
\text { psychotic and personality } \\
\text { disorders }\end{array}$ & $\begin{array}{l}\text { Architectural } \\
\text { features }\end{array}$ & $\begin{array}{l}\text { Inpatient ward, } \\
\text { outside areas }\end{array}$ & $\begin{array}{l}\text { Aggressive incidents were documented on } \\
\text { two locked wards, ward crowding was } \\
\text { modestly positively correlated with the } \\
\text { number of aggressive incidents. } \\
\text { Enlargement of the physical space by the } \\
\text { addition of a courtyard did not reduce } \\
\text { aggressive incidents. }\end{array}$ & Moderate \\
\hline $\begin{array}{l}\text { McGonagle } \\
\text { (2002) }\end{array}$ & UK & $\begin{array}{l}\text { Observational } \\
\text { comparative } \\
\text { study }\end{array}$ & $\begin{array}{l}27 \text { patients with residual } \\
\text { schizophrenia }\end{array}$ & $\begin{array}{l}\text { Architectural } \\
\text { features } \\
\text { Interior } \\
\text { design }\end{array}$ & $\begin{array}{l}\text { Community } \\
\text { facility }\end{array}$ & $\begin{array}{l}\text { After two years, patients moved to } \\
\text { purpose-built community bungalows } \\
\text { (design reflects a house dwelling, clean and } \\
\text { modern furnishings, the nursing } \\
\text { philosophy promotes the non-institutional } \\
\text { practice and greater social contact with the } \\
\text { community) showed a significantly lower }\end{array}$ & Moderate \\
\hline
\end{tabular}


Table 1 (Continued)

\begin{tabular}{|c|c|c|c|c|c|c|c|}
\hline Publication & Country & Type of study & Participants & $\begin{array}{l}\text { Design } \\
\text { intervention }\end{array}$ & $\begin{array}{l}\text { Psychiatric } \\
\text { facility }\end{array}$ & Outcome & $\begin{array}{l}\text { Quality } \\
\text { rating }\end{array}$ \\
\hline & & & & & & $\begin{array}{l}\text { level of social, behavioral problems than } \\
\text { patients on wards (institutional design and } \\
\text { approach). }\end{array}$ & \\
\hline $\begin{array}{l}\text { Bola \& } \\
\quad \text { Mosher } \\
(2003)\end{array}$ & USA & $\begin{array}{l}\text { Quasi- } \\
\text { experimental }\end{array}$ & $\begin{array}{l}179 \text { patients with } \\
\text { schizophrenia }\end{array}$ & $\begin{array}{l}\text { Architectural } \\
\text { features }\end{array}$ & $\begin{array}{l}\text { Community } \\
\text { facility }\end{array}$ & $\begin{array}{l}\text { Small, homelike, interpersonally focused } \\
\text { therapeutic milieu with non-professional } \\
\text { staff led to large effect size benefit in } \\
\text { domains of psychopathology, work, and } \\
\text { social functioning. }\end{array}$ & Moderate \\
\hline $\begin{array}{c}\text { Southard } \\
\text { (2012) }\end{array}$ & USA & Experimental & $\begin{array}{l}81 \text { acute inpatients with } \\
\text { mood/ anxiety/substance } \\
\text { use disorders, } 25 \text { nurses }\end{array}$ & $\begin{array}{l}\text { Interior } \\
\text { design }\end{array}$ & Nursing station & $\begin{array}{l}\text { The removal of the glass from the nursing } \\
\text { station had no statistically significant } \\
\text { difference in patient or staff perceptions of } \\
\text { social involvement or social support in } \\
\text { staff-patient interactions. No increase in } \\
\text { aggression toward staff was found. On the } \\
\text { contrary, seclusion and restrain rates } \\
\text { dropped. }\end{array}$ & Moderate \\
\hline $\begin{array}{l}\text { Kidd et al } \\
(2015)\end{array}$ & Canada & $\begin{array}{l}\text { Experimental } \\
\text { feasibility study }\end{array}$ & $\begin{array}{l}5 \text { patients with } \\
\text { schizophrenia }\end{array}$ & $\begin{array}{l}\text { Interior } \\
\text { design }\end{array}$ & $\begin{array}{l}\text { Patients' } \\
\text { bedrooms }\end{array}$ & $\begin{array}{l}\text { Installing digital picture frames in patients' } \\
\text { rooms prompted patient-staff } \\
\text { conversations, served as a positive } \\
\text { distraction for patients and improved their } \\
\text { physical environment. }\end{array}$ & Not rated \\
\hline \multicolumn{8}{|c|}{ MIXED-METHOD STUDIES } \\
\hline $\begin{array}{l}\text { Boydell \& } \\
\text { Everett } \\
(1992)\end{array}$ & Canada & $\begin{array}{l}\text { Quasi- } \\
\text { ethnographic }\end{array}$ & $\begin{array}{l}14 \text { long-term psychiatric } \\
\text { patients }\end{array}$ & $\begin{array}{l}\text { Architectural } \\
\text { features }\end{array}$ & $\begin{array}{l}\text { Community } \\
\text { facility }\end{array}$ & $\begin{array}{l}\text { The residential milieu (low-rise building, } \\
\text { single units with separate space for } \\
\text { collective activities) improved perceived } \\
\text { relationships and personal growth of } \\
\text { patients. No increase in patients' informal } \\
\text { social networks occurred during one year } \\
\text { post-move to supported housing. }\end{array}$ & $18 / 25$ \\
\hline $\begin{array}{l}\text { Smith and } \\
\text { Jones } \\
(2014)\end{array}$ & UK & Observational & $\begin{array}{l}7 \text { male psychiatric } \\
\text { inpatients, } 10 \text { staff }\end{array}$ & $\begin{array}{l}\text { Ambient } \\
\text { features }\end{array}$ & $\begin{array}{l}\text { Sensory/comfort } \\
\text { room }\end{array}$ & $\begin{array}{l}\text { The sensory room ( } 5 \mathrm{~m} \times 2.5 \mathrm{~m} \text {, light blue } \\
\text { painted walls, laminate flooring, one } \\
\text { window, bubble tube, light/image emitting } \\
\text { projector, variety of cushions, stress relief } \\
\text { toys and educational materials) provided a } \\
\text { place of refuge as well as de-escalation, } \\
\text { relaxation, socialization, and the ability to } \\
\text { enjoy sensory activities, especially music. } \\
\text { The majority of patients and staff believed } \\
\text { the room evoked a sense of community and } \\
\text { provided a space for socializing. In addition } \\
\text { to experiencing better engagement with } \\
\text { fellow patients, both groups believed the } \\
\text { sensory room improved staff and patient } \\
\text { communication and the overall experience } \\
\text { in the unit. }\end{array}$ & $\begin{array}{l}16 / 25 \\
\text { Moderate }\end{array}$ \\
\hline \multicolumn{8}{|c|}{ QUALITATIVE STUDIES } \\
\hline $\begin{array}{l}\text { Anderson } \\
\text { (1976) }\end{array}$ & USA & $\begin{array}{l}\text { Post-occupancy } \\
\text { evaluation }\end{array}$ & 8 hospital staff & $\begin{array}{l}\text { Architectural } \\
\text { features }\end{array}$ & Building location & $\begin{array}{l}\text { Community location facilitated interaction } \\
\text { between community groups and } \\
\text { psychiatric patients. Open communal } \\
\text { spaces coupled with the use of private } \\
\text { rooms and living rooms improved staff- } \\
\text { patients social interaction. }\end{array}$ & $12 / 25$ \\
\hline Olson (1993) & USA & $\begin{array}{l}\text { Post-occupancy } \\
\text { qualitative } \\
\text { study }\end{array}$ & $\begin{array}{l}\text { Residents with history of } \\
\text { mental illness }\end{array}$ & $\begin{array}{l}\text { Interior } \\
\text { design }\end{array}$ & $\begin{array}{l}\text { Community } \\
\text { facility } \\
\text { Communal areas }\end{array}$ & $\begin{array}{l}\text { After the renovations to two hotels (small } \\
\text { single occupancy rooms, plain, basic } \\
\text { amenities, and little communal space), } \\
\text { residents were positive about having their } \\
\text { own personalised and homelike space. } \\
\text { They criticised the units for being too small, } \\
\text { without space to have visitors. The majority } \\
\text { felt that several functionally distinct social } \\
\text { spaces would improve their housing (e.g. } \\
\text { small lounge for TV viewing, separate game } \\
\text { and music room, an outdoor patio, small } \\
\text { visiting areas, quiet areas to sit and read or } \\
\text { have a small-room meeting). These } \\
\text { communal areas should be well-furnished, } \\
\text { colourful, with bookcases and living plants. }\end{array}$ & $12 / 25$ \\
\hline Parr (2000) & UK & $\begin{array}{l}\text { Ethnographic } \\
\text { study }\end{array}$ & $\begin{array}{l}30 \text { people with mental } \\
\text { illness }\end{array}$ & $\begin{array}{l}\text { Interior } \\
\text { design }\end{array}$ & $\begin{array}{l}\text { Community } \\
\text { facility }\end{array}$ & $\begin{array}{l}\text { The inner city, drop-in day centre was a } \\
\text { large room bordered by an office and a } \\
\text { kitchen hatch with a pool table positioned } \\
\text { opposite to tables with four chairs. The use } \\
\text { of this space allowed people who wanted to } \\
\text { be alone to sit around the pool table and } \\
\text { watch the pool without interacting with } \\
\text { others and people who wanted social }\end{array}$ & $17 / 25$ \\
\hline
\end{tabular}


Table 1 (Continued)

\begin{tabular}{|c|c|c|c|c|c|c|c|}
\hline Publication & Country & Type of study & Participants & $\begin{array}{l}\text { Design } \\
\text { intervention }\end{array}$ & $\begin{array}{l}\text { Psychiatric } \\
\text { facility }\end{array}$ & Outcome & $\begin{array}{l}\text { Quality } \\
\text { rating }\end{array}$ \\
\hline & & & & & & $\begin{array}{l}\text { interaction to gather around the tables with } \\
\text { chairs. }\end{array}$ & \\
\hline Curtis (2007) & UK & $\begin{array}{l}\text { Post-occupancy } \\
\text { evaluation }\end{array}$ & 7 inpatients, 13 staff & $\begin{array}{l}\text { Architectural } \\
\text { features }\end{array}$ & $\begin{array}{l}\text { Building location } \\
\text { Hospital } \\
\text { Communal areas } \\
\text { Bedrooms } \\
\text { Smoking rooms }\end{array}$ & $\begin{array}{l}\text { Patients and staff require both interactive } \\
\text { and private spaces. Patients occasionally } \\
\text { want to 'escape' from staff and identify } \\
\text { smoking places and separate communal } \\
\text { areas (e.g. female lounge) as ideal for that } \\
\text { purpose. }\end{array}$ & $16 / 25$ \\
\hline $\begin{array}{l}\text { Donald } \\
\text { (2015) }\end{array}$ & Australia & $\begin{array}{l}\text { Observational } \\
\text { qualitative } \\
\text { study }\end{array}$ & 20 psychiatric inpatients & $\begin{array}{l}\text { Architectural } \\
\text { features } \\
\text { Interior } \\
\text { design }\end{array}$ & $\begin{array}{l}\text { Inpatient wards } \\
\text { Outdoor space }\end{array}$ & $\begin{array}{l}\text { Patients described the ward's built } \\
\text { environment as 'confusing' (e.g. being } \\
\text { between a hospital and a home without } \\
\text { being either). Patients complained of } \\
\text { boredom, unit's limited amenities and } \\
\text { opportunities for community integration. } \\
\text { The closure of the courtyard instigated } \\
\text { patients' feelings of confinement and a } \\
\text { natural vision for the ward. }\end{array}$ & $20 / 25$ \\
\hline $\begin{array}{l}\text { Johansson } \\
\text { (2007) }\end{array}$ & Sweden & $\begin{array}{l}\text { Ethnographic } \\
\text { study }\end{array}$ & $\begin{array}{l}12 \text { acute inpatients with } \\
\text { affective and eating } \\
\text { disorders, } 25 \text { staff }\end{array}$ & $\begin{array}{l}\text { Architectural } \\
\text { features }\end{array}$ & $\begin{array}{l}\text { Inpatient ward } \\
\text { Communal areas }\end{array}$ & $\begin{array}{l}\text { The communal areas of the ward (e.g. } \\
\text { combined dining and day room, patients' } \\
\text { corridor, activity room and smoking room) } \\
\text { were identified as the key social spaces } \\
\text { containing a mix of encounters between } \\
\text { people, in a continuum of professional care } \\
\text { to private meetings and social events. }\end{array}$ & $16 / 25$ \\
\hline $\begin{array}{l}\text { Shattell } \\
\quad(2008)\end{array}$ & USA & $\begin{array}{l}\text { Observational } \\
\text { qualitative } \\
\text { study }\end{array}$ & $\begin{array}{l}10 \text { inpatients with mood, } \\
\text { anxiety, or substance } \\
\text { misuse, } 9 \text { female nurses. }\end{array}$ & $\begin{array}{l}\text { Interior } \\
\text { design }\end{array}$ & Nursing station & $\begin{array}{l}\text { Nurses felt caged in by the plexiglass- } \\
\text { enclosed nursing station and reported that } \\
\text { the unit included 'too much nursing station } \\
\text { space and not enough patient interaction } \\
\text { space.' Participants received support } \\
\text { mostly from members of their peer groups: } \\
\text { patients supported patients and nurses } \\
\text { supported nurses. }\end{array}$ & $18 / 25$ \\
\hline $\begin{array}{l}\text { Skorpen } \\
(2008)\end{array}$ & Norway & $\begin{array}{l}\text { Ethnographical } \\
\text { study }\end{array}$ & $\begin{array}{l}16 \text { psychiatric inpatients } \\
\text { and } 23 \text { staff, } 19^{\text {th }} \text { century } \\
\text { asylum }\end{array}$ & $\begin{array}{l}\text { Architectural } \\
\text { features }\end{array}$ & $\begin{array}{l}\text { Inpatient ward } \\
\text { Smoking room }\end{array}$ & $\begin{array}{l}\text { The design and architectural placement of } \\
\text { the smoking room gave the patients privacy } \\
\text { and a surveillance point to gain information } \\
\text { about the ward's activities. Patients found } \\
\text { that beneficial as the smoking room } \\
\text { became a place for genuine peer support. } \\
\text { Despite Spartan furnishing, the room } \\
\text { carried an atmosphere that included } \\
\text { laughter, seriousness and corrections with } \\
\text { many unspoken rules. }\end{array}$ & $16 / 25$ \\
\hline $\begin{array}{l}\text { Parrott } \\
\qquad(2010)\end{array}$ & UK & Ethnographic & $\begin{array}{l}7 \text { female and } 12 \text { male } \\
\text { forensic inpatients with } \\
\text { severe mental illness }\end{array}$ & $\begin{array}{l}\text { Interior } \\
\text { design }\end{array}$ & Inpatient ward & $\begin{array}{l}\text { The design of units was intended to } \\
\text { embody an ethos of domesticity: short } \\
\text { corridors, single bedrooms, open-plan } \\
\text { sitting and dining room with wide-screen } \\
\text { television, bowls of fruit and plants, and } \\
\text { access to a garden from various spaces. The } \\
\text { setting also featured architecture of } \\
\text { security and surveillance (e.g. perimeter } \\
\text { fencing, windows that could not be fully } \\
\text { opened, panic alarms and double-locked } \\
\text { entrance and exit doors).Patients aspired to } \\
\text { retain a sense of the artificiality of their } \\
\text { hospital stay, preferring to confine their } \\
\text { notion of 'real' relationships to those that } \\
\text { exist outside the institution. Potentially } \\
\text { isolating activities (e.g. watching television } \\
\text { and looking at photographs in their room) } \\
\text { are helpful to counter feelings of loneliness } \\
\text { and isolation. }\end{array}$ & $14 / 25$ \\
\hline $\begin{array}{r}\text { Novotna } \\
(2011)\end{array}$ & Canada & $\begin{array}{l}\text { Pre-post } \\
\text { occupancy }\end{array}$ & $\begin{array}{l}72 \text { substance misuse } \\
\text { patients, } 40 \text { staff }\end{array}$ & $\begin{array}{l}\text { Architectural } \\
\text { features }\end{array}$ & $\begin{array}{l}\text { Building location } \\
\text { Communal areas }\end{array}$ & $\begin{array}{l}\text { The move from two traditionally designed } \\
\text { inpatient units to the new facility with low- } \\
\text { rise buildings, homelike design, single en- } \\
\text { suite bedrooms, shared kitchen and dining } \\
\text { area, living and multipurpose rooms led to } \\
\text { increased patients-staff communications; } \\
\text { preferred boundaries for both staff and } \\
\text { patients; and reduced stigma of mental } \\
\text { illness by increasing positive interactions } \\
\text { with family. }\end{array}$ & $18 / 25$ \\
\hline $\begin{array}{l}\text { Wood et al } \\
\text { (a) (2013) }\end{array}$ & UK & $\begin{array}{l}\text { Pre-post } \\
\text { relocation } \\
\text { ethnographic } \\
\text { study }\end{array}$ & $\begin{array}{l}9 \text { carers, staff (number not } \\
\text { given). }\end{array}$ & $\begin{array}{l}\text { Architectural } \\
\text { features }\end{array}$ & Visiting rooms & $\begin{array}{l}\text { The move from a nineteenth-century } \\
\text { asylum with a recreation hall to a purpose- } \\
\text { built new hospital with more 'quiet' rooms } \\
\text { used for family visits had multiple } \\
\text { outcomes on patient-visitor interactions. }\end{array}$ & $19 / 25$ \\
\hline
\end{tabular}


Table 1 (Continued)

\begin{tabular}{|c|c|c|c|c|c|c|c|}
\hline Publication & Country & Type of study & Participants & $\begin{array}{l}\text { Design } \\
\text { intervention }\end{array}$ & $\begin{array}{l}\text { Psychiatric } \\
\text { facility }\end{array}$ & Outcome & $\begin{array}{l}\text { Quality } \\
\text { rating }\end{array}$ \\
\hline & & & & & & $\begin{array}{l}\text { Carers and family members spent time in } \\
\text { both indoor and outdoor areas. Carers } \\
\text { valued the recreational hall and a space } \\
\text { which allows people to practise their } \\
\text { religious belief, thus supporting } \\
\text { connections with family and community } \\
\text { members. }\end{array}$ & \\
\hline $\begin{array}{l}\text { Wood et al } \\
\text { (b) (2013) }\end{array}$ & UK & $\begin{array}{l}\text { Pre-post } \\
\text { relocation }\end{array}$ & 114 patients, carers, staff & $\begin{array}{l}\text { Architectural } \\
\text { features }\end{array}$ & Smoking spaces & $\begin{array}{l}\text { The new purpose-built hospital provided } \\
\text { outdoor shelters for use by smokers. Since } \\
\text { staff no longer needed to escort patients off } \\
\text { the wards to smoke, this contributed to a } \\
\text { more therapeutic landscape, facilitating a } \\
\text { more relaxed regime that gave patients an } \\
\text { enhanced sense of personal freedom. The } \\
\text { shelters were deliberately small which was } \\
\text { problematic for patients during rainy days. }\end{array}$ & $18 / 25$ \\
\hline $\begin{array}{l}\text { Shattell } \\
\text { (2015) }\end{array}$ & USA & $\begin{array}{l}\text { Observational } \\
\text { qualitative } \\
\text { study }\end{array}$ & $\begin{array}{l}13 \text { acute inpatients, } 16 \text { staff } \\
\text { members }\end{array}$ & $\begin{array}{l}\text { Interior } \\
\text { design }\end{array}$ & nursing station & $\begin{array}{l}\text { Nurses had mixed feelings about the } \\
\text { enclosure, reporting that it provided for } \\
\text { confidentiality and a concentrated work } \\
\text { space but also acknowledged the challenge } \\
\text { of the barrier for communication with their } \\
\text { patients. Patients unanimously preferred } \\
\text { the nurses' station without the barrier, } \\
\text { reporting increased feelings of freedom, } \\
\text { safety, and connection with the nurses after } \\
\text { its removal. }\end{array}$ & $18 / 25$ \\
\hline
\end{tabular}

\subsection{Architectural typology and external image}

Psychiatric facilities are built in a wide range of sizes and architectural typologies [27,28]. The purpose-built facilities are usually organized with the central section set aside primarily for offices and activity areas and the wings for patient rooms. Eight studies explored what happened when patients were relocated from nineteenth century or early twentieth century hospitals to new, smaller, homelike, purpose built facilities. Old facilities were described as overcrowded, institutional environments with multibed rooms, cramped communal areas and lack of private spaces. Six studies showed that new environments were beneficial for social interactions, and patients reported greater satisfaction with their environment and received care [4,20,21,29-31]. Two studies showed that relocation led to no difference in perceived social support (functional measure of social interaction) [32,33]. Shepherd and colleagues compared five long-stay inpatient facilities and 20 community facilities to find out that inpatient facilities were characterised with poorer physical environment and significantly less staff-patient interactions [34]. A new type of psychiatric care often requires new type of environment. For example, the Soteria project provided a small (10-12 patients), homelike, intensive, interpersonally focused therapeutic milieu where patients exhibited a large effect size benefit in domains of psychopathology, work, and social functioning [35].

Three studies addressed the role of corridors. Sommer and Gilliland [36] found that patients who were friendless tended to congregate in the corridors (56\% compared to $31 \%$ in day room). Another study restructured an acute 30 -bed ward by breaking up long corridors and as a result, social interaction increased, interactions moved from corridors to a visiting room and a cafeteria, and there was a marked increase of visitors [37]. Srivastava and Good [38] showed that the location of communal areas at the extreme ends of bedroom and service wings activated the connecting corridors.

\subsection{Interior design interventions}

Twenty-eight studies explored the role of interior design in changing social interactions. Interventions such as socio-petal furniture rearrangement (chairs arranged around tables) $[39,40]$, installation of waist-high partitions to promote private conversations [37,38,41,42], new residential furnishings [43], introduction of plants [43], and availability of leisure-time resources (e.g. games, cards, books, magazines) $[39,40,44,45]$ have been found to facilitate and increase social interactions. Two studies showed that interventions such as changes in furniture style, floor covering, and colour scheme, can improve staff members' and patients' satisfaction with new environments but have no effect on perceived social support [46] or social isolation [41].

\subsection{Specific spaces within psychiatric facilities}

\subsubsection{Communal areas - key social spaces}

Eleven studies explored the design of communal areas within psychiatric facilities. Several studies have identified lounges, dining rooms, and lobby areas as key social spaces which serve as locations for meetings with family members, having casual interactions with peers and staff, and for participating in structured therapeutic activities [30,38,47-49]. Two studies showed that when patients are offered to use communal spaces, they usually take up this opportunity and social encounters tend to move from corridors and bedrooms into communal areas [37,50]. Howeverdue to redistribution of social activity, isolated and withdrawn behaviour can still appear in another place [49,51]. The provision of several functionally distinct social spaces can allow opportunities for activities which replicate family life and social activity in the community [30,32,52,53].

\subsubsection{Patients' bedrooms}

Individual bedrooms can give patients freedom to withdraw when feeling unwell and to determine their own rhythm of activities [25]. Only one study focused specifically on the bedroom size and function. Ittelson and colleagues observed social behaviour of psychiatric patients in three large hospitals in the USA with varying bedroom sizes, and found that wards with single or double rooms had more social activity, while dormitory rooms had more isolated passive behaviour (e.g. lying on a bed) [51]. Patients tend to decorate and personalise their rooms and two studies identified patients' personal objects and photographs as 
important mediators of sociability [54,55]. In a small pilot study, Kidd and colleagues installed digital picture frames in patients' rooms and this prompted patient-staff conversations, served as positive distraction for patients and improved patients' appraisal of physical environment [55].

\subsubsection{Nursing stations}

Nursing stations are focal points of staff-patients interactions, and these interactions tend to gradually decrease with a larger distance from nursing stations [38,56]. The impact of an open vs. closed nursing station was addressed in six publications. Shattell and colleagues reported that the nurses felt caged-in by the plexiglas-enclosed nursing station [6]. After the glass had been removed, there were no statistically significant differences in patient or staff perceptions of social involvement or social support [57]. A qualitative study of the same intervention showed that nurses had mixed feelings about the intervention. Patients unanimously preferred the nurses' station without the barrier, reporting increased feelings of freedom, safety, and connection with the nurses after its removal [6]. Two studies showed that the removal of the glass panel significantly increased staff-patient interactions $[4,58]$. Whitehead showed that open nursing stations motivated staff to interact with patients [37].

\subsubsection{Smoking rooms}

Three studies have indicated that the space in which patients smoke can serve as a platform for positive social interactions and resistance to institutional control $[23,25,30]$. Skorpen and colleagues reported that patients considered the smoking room as their own arena and a place for genuine peer support, mainly because staff was not able to observe all the interactions going on in the room [23]. Wood and colleagues explored the role of smoking areas in a newly built psychiatric hospital [59]. In the old hospital, there had been a gradual change from the days where everywhere was regarded as a smoking area to dedicated smoking rooms that over time were reduced to the size of telephone boxes in order to discourage patients from spending time there. The new hospital provided smoking shelters in the courtyards and since staff no longer needed to escort patients off the wards to smoke, this contributed to a more relaxed regime that gave patients an enhanced sense of personal freedom.

\subsubsection{Outdoor spaces}

Five studies explored the role of outdoor spaces and links between indoor and outdoor spaces. Srivastava and Lawrence showed that social groups on psychiatric wards commonly tended to form near windows which visually connected the ward with the outside world [38]. In a pre- and post-relocation study, Long and colleagues found that patients preferred wards with social areas with windows, visibility and better access to outdoor (trees and lawns) and with interior green space (courtyards with plants and water features), however, these features had no effect on perceived social support [33]. In another study, fresh air was mentioned to decrease the 'suffocating' feeling of the acute care environment [6]. Importantly, patients reported their frustration because although available, the courtyards were difficult to access and patients often felt trapped on wards [5]. Carers have also emphasised their preference for domestic gardens in psychiatric facilities which they could visit with their family members [30].

\subsection{Ambient features}

The role of ambient features has received significantly less attention compared to architectural and interior design interventions. Smith and Jones [60] explored patients and staff perspection of a sensory room at a psychiatric intensive care unit.
The room provided stimuli (e.g. lights, sounds, textures) and staff support for individual or group-based intervention to encourage patients to decrease stress, anger, and anxiety. The majority of patients and staff believed the room evoked a 'sense of community' and provided a space for socializing. In a pre-post renovation study, researchers found no significant effect of changes in lighting on social behaviour on wards [43].

\subsection{The relationship between physical environment, positive and negative social interactions}

Eleven studies explored the relationship between physical environment and negative social interactions within psychiatric facilities. A large study of 199 psychiatric wards in the Netherlands identified 14 design features with significant effect on the risk of being secluded during admission [61]. For example, the presence of an outdoor space, special safety measures, and patient overcrowding increased the risk of being secluded, while features such as more total private space per patient, a higher level of comfort and greater visibility on the ward decreased the risk of being secluded. The study controlled for length of stay, patient characteristics, general ward characteristics, and number of staff. The finding of an increase in risk of seclusion with the presence of an outdoor space or garden is not consistent with the literature. The authors suggested that this finding may have been biased because their data was limited to two items:the presence of an outdoor space (yes/no) and the height of the fences. Other relevant information such as the quality or attractiveness of the outdoor space or garden and whether or not patients actually had (free and/ or unsupervised) access to the outdoor space, was not documented [61]. Seven studies showed that renovation $[41,57,62]$ or relocation of patients to a new, purpose build facility [63-66] was associated with reduction in violent incidents, seclusion or restraint. Southard and colleagues showed that the removal of the glass from the nursing station did not lead to increase in aggression toward staff, on the contrary, seclusion and restrain rates dropped [57]. Several studies showed that interventions such as enlargement of the physical space [67-69] or rearrangement of ward furniture [40] were not associated with significant decline in incidents. In one of these studies the new unit was substantially larger, but operated with the same number of staff which may have prevented better use of the new space $[67,68]$.

\subsection{Robustness of synthesis}

The overall strength of evidence was moderate. The mean RATS score for the 22 qualitative studies was 15.1 (range 12-19), including 15 high quality studies (RATS $\geq 15$ ) and 7 moderate quality studies (RATS $=12-14$ ). The Effective Public Health Practice Project (EPHPP) ratings for 27 quantitative studies indicated they were of moderate quality. One study was not rated because of insufficient information on methodology within this paper [55]. One study included both qualitative and quantitative components [60]; both were rated as moderate quality. In two areas the quality of studies was problematic. Only ten of the included studies considered researcher bias influencing results. Secondly, 16 studies reported information on ethical issues or ethics approval. Studies published in 1970s and 1980s largely did not report this information. All papers were rated by two reviewers (NJ and JC) who achieved acceptable concordance (93\%).

\section{Discussion}

The review identified several design features that-based on the existing evidence-may be regarded as fostering social interactions in psychiatric facilities. The main ones include community 
location; newly designed or renovated, small (up to 20 beds), homelike facilities with a wide range of communal areas; single/ double bedrooms; open nursing stations; right balance between private and shared spaces; and specific design interventions such as arranging furniture in small, flexible groupings (see Table 2). The level of evidence linking these design features to the level of social interaction among the users of psychiatric facilities is low to moderate which is often in line with research in other medical fields [9]. However, the exception is the finding that levels of social interaction increase when introducing a range of communal spaces with comfortable, movable furniture arranged in small, flexible groupings. This evidence is notably strong because it stems from well-designed, randomised-controlled trials conducted in the 1970s [39,70,71]. In the following decades studies in this field were mainly observational with/without controls and no randomised-controlled trial had been conducted to explore the links between design solutions and social interaction (see Table 1).

Several findings from this review warrant further discussion. For example, we found that building psychiatric facilities within local communities rather than in isolated locations might improve patient interaction with others. However, it is important to emphasise that this alone is not enough to help patients to increase the size of their social networks or renew family relationships, which suggests the need for a new way of conceiving psychiatric environments. Design needs to engage people, creating opportunities for more interaction between community members and patients in or close to psychiatric facilities $[5,20,26]$. Similarly, homelike environments might be beneficial for social interactions between staff, patients and carers because they allow opportunities for the replication of family and community activities. One of the important themes identified in this review was the balance between private and shared spaces. In order to engage in positive interactions both staff and patients need to have their own space to retreat when feeling overwhelmed $[4,6,51,72]$. The design of these spaces can include 'territorial' demarcations that separate 'interaction' from 'private' spaces, thus helping patients and staff to exercise choice over how and when they use the space [73]. Patients' private spaces are their bedrooms, and our findings indicate that single and double bedrooms are more beneficial for social interactions than multi-bed dormitories. Studies from other medical disciplines show that single rooms are better for patientfamily interactions (by providing more space and furniture than double rooms) [74,67], while double bedrooms may have benefits for patient-patient interactions [75,68]. A systemic approach to social interaction in psychiatric facilities would treat violent incidents as types of interactions [69]. The question is whether a reduction in violent incidents would increase chances for positive interactions. This remains unclear and we were not able to identify studies exploring that question. Several studies showed that renovation or relocation of patients to a new facility was associated with reduction in violent incidents, seclusion or restraint. As explained by Borckardt and colleagues, the physical changes to the environment served as constant reminders to staff of the commitment to behavioural change such as eliminating use of seclusion and restraint [62]. Perhaps, the balance between private and shared spaces may be the key in understanding this relationship because violent incidents are more likely to occur on crowded wards with higher average noise level, more patientpatient interactions, and less opportunities for patients to find rest or privacy $[67,76]$. There are two types of spaces that have specific connotations in psychiatric facilities: corridors and smoking rooms. While studies from other medical disciplines have identified long corridors as inefficient for staff [11], in psychiatric hospitals, this feature can also be detrimental for patients by fostering social isolation [36,37]. Psychiatric patients have identified smoking rooms as important spaces that can offer 'escape' from observation and institutional control. With the smoking ban in place in psychiatric facilities in many countries, the question is which places will provide the same function for patients. The answer may not lie in the design of hospital environments, but rather in the type of provided care and risk management. The introduction of a comprehensive smoke-free policy seems not only

Table 2

Key design interventions that can facilitate positive interactions among users of mental healthcare facilities.

Design interventions

Location/Site

Building/architectural features

Interior design

Ambient features

$\begin{array}{cl}\text { SPECIFIC } & \text { Corridors } \\ \text { SPACESS } & \text { Communal } \\ & \text { areas } \\ & \text { Patient } \\ \text { bedrooms } \\ \text { Nursing } \\ \text { station } \\ \text { Smoking } \\ \text { rooms }\end{array}$

Building mental health facilities within local communities vs in isolated locations can have several advantages: to encourage patients to spend more time in the community and use local resources [20-22], to enable families to regularly visit patients [25,47], and to reduce stigma of mental illness and mentally ill patients [47].

Architectural typology that resembles hotel/hostel/bungalow-type with external image blended with the neighbourhood scale and building forms is preferred by patients, staff, and carers. Six studies showed that relocating patients from asylums to new, smaller, homelike, purpose-built facilities was beneficial for social interaction [4,20,21,29-31] Seven studies showed that renovation [41,57,62] or relocation of patients to a new, purpose build facility [63-66] was associated with reduction in violent incidents, seclusion or restraint.

Arranging furniture in flexible groupings (even short-term) [39,40], new residential furnishings [43], introduction of plants [43], and installing waist-high partitions to promote private conversations $[38,41,42]$ have been found to increase social interactions. Chairs should not be arranged shoulder to shoulder along the walls of the room. Games, cards, books, magazines placed on tables can facilitate social interaction $[39,40,44]$. Patients' photographs, cards and gifts from family or friends can be considered as important mediators of sociability [54].

Sensory (comfort) room is a place where stimuli such as lights, sounds, textures, and staff support can be used with patients during deescalation, self-regulation, and calming. Patients consider this room to provide sense of community and a space for socializing [60]. Overall little research was available.

Long corridors should be avoided; socially isolated patients tend to congregate in the corridors [36]. Interventions to break up long corridors were found to be beneficial for social interaction [37].

The provision of a wide range of social spaces (e.g. smaller and bigger lounges, visiting areas) and good balance between private and shared spaces is beneficial for social interaction. Both staff and patients need private spaces to retreat from intensive interactions. The provision of single or double bedrooms vs large dormitories can increase social activity [51].

Opened nursing stations are preferred by patients and staff and tend to increase staff-patient interactions [4,37,58].

Despite small size and poor furnishing, patients valued these places as their arena and place for genuine peer support [23,25,59]. The introduction of a comprehensive smoke-free policy seems to be beneficial for patients' health but also appears to reduce the incidence of physical assaults [77].

Outdoor areas The provision of courtyards and gardens was valued by patients and visitors [5,6,30], but access is often problematic. Overall little research evidence was available. 
be beneficial for patients' health but also appears to reduce the incidence of physical assaults [77]. Despite anecdotal evidence that rooms for group psychotherapy, occupational therapy and arts therapies can facilitate social interaction, we were unable to identify studies exploring this topic.

The review has both strengths and limitations. This is the first systematic review of architectural typologies and design solutions that can potentially foster positive social interactions in psychiatric facilities and, thus, may help patients in re-establishing their social roles in the community. Using social interactions as an outcome, we focused our aim on a more robust, behavioural criterion which was helpful in clearly defining the evidence. Our synthesis was moderately robust and was limited by the fact that several studies used small convenience samples or pre- and post- assessments with no control group. The studies included both direct and indirect measurements of social interaction. The interpretation of indirect measures such as perceived social support may be problematic because the interaction between physical and social environment appears to be actively filtered by the individual's perception and possibly mental health problems [78]. Although the review focused on adult settings (age 18-65), one study included a proportion of old age patients [43] and one study included a proportion of old age and adolescent patients [62]. The review focused on built environment aspects of the patient experience of a psychiatric facility and while maintaining this focus was needed to address our research question, we are aware that the overall patient experience may be influenced by a number of social and cultural influences. Studies included in this review were conducted in developed, Western healthcare systems and translating the findings into other countries and healthcare systems needs to take into consideration the role of relevant cultural and social factors. Despite these limitations, the study adds to the literature on hospital built environment by identifying several candidate interventions that could be considered when planning psychiatric facilities.

The main implication for practice is that there is considerable evidence that should be taken into account when planning or renovating psychiatric facilities. The review attempted to identify architectural typologies and design solutions which could foster helpful social interactions between users of psychiatric facilities. We hope that this will contribute to further understanding of the milieu of psychiatric facilities. Our findings can guide future design interventions, but it is important to emphasise that design or retrofitting of a psychiatric facility is a complex process. How design solutions identified in this review could potentially fit together can depend on a number of factors. For example, the environmental interventions in psychiatric facilities always need to consider safety of patients, staff, and visitors, which can be seen as both challenge and opportunity for designers and mental health professionals to come up with innovative solutions. Next, the process of design and renovation need to include patients, staff, and families to ensure that their values, beliefs and cultural backgrounds are incorporated into the planning and delivery of care. Lastly, a proactive plan can anticipate budget restrictions which may involve trade-offs or building in phases.

\section{Conclusion}

The design of psychiatric facilities, from needs assessments and program planning to the creation of new spaces should be guided by research evidence. This study has identified a set of interventions that should be considered in the design of psychiatric buildings to the same extent as other factors such as cost, maintenance, and harmony. Some of the identified design interventions are easy and non-costly to implement in existing hospitals (e.g. socio-petal furniture arrangement, residential-like furniture), whilst others require major investment and can be established only in new buildings (e.g. range of social spaces, good balance between social and private spaces). The findings might be particularly helpful to colleagues in countries that are moving from asylum-based to community-based services. Research in this field has been largely focused on inpatient settings. Future research should pursue well-designed studies on outpatient settings and supported housing as well as on the role of outdoor spaces.

\section{Funding}

This research did not receive any specific grant from funding agencies in the public, commercial, or not-for-profit sectors.

\section{References}

[1] Mental health action plan. World Health Organization Regional Office for Europe; 2013.

[2] Tyson GA, Lambert G, Beattie L. The impact of ward design on the behaviour occupational satisfaction and well-being of psychiatric nurses. Int J Ment Health Nurs 2002;11(2):94-102.

[3] Plantamura F, Capolongo S, Oberti I. Built environment and wellbeing in Italian psychiatric wards. World Hosp. Health Serv. 2015;51:36-9.

[4] Chrysikou E. Architecture for psychiatric environments and therapeutic spaces. UCL Discovery; 2014.

[5] Donald F, Duff C, Lee S, Kroschel J, Kulkarni J. Consumer perspectives on the therapeutic value of a psychiatric environment. J Ment Health 2015;24(2):637.

[6] Shattell MM, Andes M, Thomas SP. How patients and nurses experience the acute care psychiatric environment. Nurs Inq 2008;15(3):242-50.

[7] Sharac J, McCrone P, Sabes-Figuera R, Csipke E, Wood A, Wykes T. Nurse and patient activities and interaction on psychiatric inpatients wards: a literature review. Int J Nurs Stud 2010;47(7):909-17.

[8] Thomas SP, Shattell M, Martin T. What's therapeutic about the therapeutic milieu? Arch Psychiatr Nurs 2002;16(3):99-107.

[9] Ulrich RS. Essay: evidence-based health-care architecture. Lancet 2006;368: S38-9.

[10] Hamilton DK, Watkins DH. Evidence-based design for multiple building types. Wiley; 2009.

[11] Ulrich RS, Zimring C, Zhu X, DuBose J, Seo HB, Choi YS, et al. A review of the research literature on evidence-based healthcare design. HERD 2008;1:61125.

[12] Ulrich RS. Effects of interior design on wellness: theory and recent scientific research. J Health Care Inter Des 1991;3:97-109.

[13] D. Moher, A. Liberati, J. Tetzlaff, Altman DG, Preferred reporting items for systematic reviews and meta-analyses: the PRISMA statement PLoS Med 2009; 6: (7) e1000097.

[14] Harris PB, McBride G, Ross C, Curtis L. A place to heal: environmental sources of satisfaction among hospital Patients1. J Appl Soc Psychol 2002;32(6):1276-99.

[15] Quality assessment tool for quantitative studies. Project EPHP; 1998. Available from: https://merst.ca/ephpp/-Availablefrom:https://merst.ca/ ephpp/p.

[16] Clark JP. Qualitative research review guidelines -RATS, how to peer review a qualitative manuscript. In: Godlee F, Jefferon T, editors. Peer review in health sciences. second edition London: BMJ Books; 2003. p. 219-35.

[17] Popay J, Roberts H, Sowden A, Petticrew M, Arai L, Rodgers M, et al. Guidance on the conduct of narrative synthesis in systematic reviews. Available from:. A Product from the ESRC Methods Programme; 2006. http://citeseerx.ist.psu. edu/viewdoc/download?doi=10.1.1.178.3100\&rep=rep1\&type=pdf.

[18] Fornara F, Andrade CC. The oxford handbook of environmental and conservation psychology. Health Care Environments; 2012. p. 295-315.

[19] Evans G. The built environment and mental health. J Urban Health 2003;80 (4):536-55.

[20] Anderson SE, Good LR, Hurtig WE. Designing a mental health center to replace a county hospital. Psychiatr Serv 1976;27(11):807-13.

[21] Gibbons JS, Butler JP. Quality of life for_new_long-stay psychiatric in-patients. Br J Psychiatry 1987; 151(03):347-54.

[22] Davidson L, Tebes JK, Rakefeldt J, Sledge WH. Differences in social environment between inpatient and day hospital- crisis respite settings. Psychiatr Serv 1996;47(7):714-20.

[23] Skorpen A, Anderssen N, OEYE C, Bjelland AK. The smoking-room as psychiatric patients' sanctuary: a place for resistance. J Psychiatr Ment Health Nurs 2008;15(9):728-36.

[24] Boydell KM, Everett B. What makes a house a home? An evaluation of a supported housing project for individuals with long-term psychiatric backgrounds. Can J Community Ment Health 1992;11(1):109-23.

[25] Curtis S, Gesler W, Fabian K, Francis S, Priebe S. Therapeutic landscapes in hospital design: a qualitative assessment by staff and service users of the design of a new mental health inpatient unit. Environ Plann C Gov Policy 2007;25(4):591-610. 
[26] Curtis S, Gesler W, Priebe S, Francis S. New spaces of inpatient care for people with mental illness: a complex _rebirth_of the clinic? Health Place 2009;15 (1):340-8.

[27] Not just bricks and mortar: report of the Royal College of Psychiatrists Working Party on the size, structure, siting and security of new acute adult psychiatric in-patient units. Royal College of Psychiatrists Council; 1998.

[28] Australasian health facility guidelines. Sydney: Centre for Health Assets Australasia; 2007.

[29] McGonagle IM, Allan S. A comparison of behaviour in two differing psychiatric long-stay rehabilitation environments. J Psychiatr Ment Health Nurs 2002;9 (4):493-9.

[30] Wood VJ, Curtis SE, Gesler W, Spencer IH, Close HJ, Mason J, et al. Creating therapeutic landscapes for mental health carers in inpatient settings: a dynamic perspective on permeability and inclusivity. Soc Sci Med 2013;91:122-9.

[31] Wykes T. A hostel ward for_new_long stay patients: an evaluative study of_a ward in a house_. Psychol Med Monogr Suppl 1982;2:59-97.

[32] Nicholls D, Kidd K, Threader J, Hungerford C. The value of purpose built mental health facilities: use of the ward atmosphere scale to gauge the link between milieu and physical environment. Int J Ment Health Nurs 2015;24(4):286-94.

[33] Long CG, Langford V, Clay R, Craig L, Hollin CR. Architectural change and the effects on the perceptions of the ward environment in a medium secure unit for women. Br J Forensic Pract 2011;13(3):205-12.

[34] Shepherd G, Muijen M, Dean R, Cooney M. Residential care in hospital and in the community _ quality of care and quality of life. Br J Psychiatry 1996;168 (04):448-56.

[35] Bola J, Mosher L. Treatment of acute psychosis without neuroleptics: two-year outcomes from the soteria project. J Nerv Ment Dis 2003;191(4):219-29.

[36] Sommer R, Gilliland GW. Design for friendship. Canad Archit 1961;(6):59-61.

[37] Whitehead CC, Polsky RH, Crookshank C, Fik E. Objective and subjective evaluation of psychiatric ward redesign. Am J Psychiatry 1984;141(5):639-44.

[38] Srivastava R, Lawrence G. Patterns of group interactions in three architecturally different psychiatric treatment sections. Milieu Newslett 1968;1:1-10.

[39] Holahan C. Seating patterns and patient behavior in an experimental dayroom. J Abnorm Psychol 1972;80(2):115-24.

[40] Baldwin S. Effects of furniture rearrangement on the atmosphere of wards in a maximum-security hospital. Hosp Community Psychiatry 1985;36(5):525-8.

[41] Christenfeld R, Wagner J, Pastva WG, Acrish WP. How physical settings affect chronic mental patients. Psychiatr Q 1989;60(3):253-64.

[42] Holahan CJ, Saegert S. Behavioral and attitudinal effects of large-scale variation in the physical environment of psychiatric wards. J Abnorm Psychol 1973;82 (3):454-62.

[43] Devlin AS. Psychiatric Ward Renovation. Environ Behav 1992;24(1):66-84.

[44] Collins JF, Casey NA, Hickey RH, Twemlow SW, Ellsworth RB, Hyer L, et al. Treatment characteristics of psychiatric programs that correlate with patient community adjustment. J Clin Psychol 1985;41(3):299-308.

[45] Rice CG, Talbott JA, Stern D. Effects of environmental agents on social behavior of patients in a hospital dining room. Psychiatr Serv 1980;31(2):128-30.

[46] Corey LJ, Wallace MA, Harris SH, Casey B. Psychiatric ward atmosphere. J Psychosoc Nurs Ment Health Serv 1986;24(10):10-6.

[47] Novotna G, Urbanoski KA, Rush BR. Client-centered design of residential addiction and mental health care facilities. Qual Health Res 2011;21(11):152738.

[48] Johansson I IS, Danielson E. Encounters in a locked psychiatric ward environment. J Psychiatr Ment Health Nurs 2007;14(4):366-72.

[49] Fairbanks LA, McGuire MT, Cole SR, Sbordone R, Silvers FM, Richards M, et al. The ethological study of four psychiatric wards: patient, staff and system behaviors. J Psychiatr Res 1977;13(4):193-209.

[50] Muller N, Blumenberg U, Keul AG. Gestaltung, Ausstattung und Funktionalit_t psychiatrischer Stationen: eine Vergleichsuntersuchung. Krankenhauspsychiatrie 1996; 7:143-50.

[51] Ittelson WH, Proshansky HM, Rivlin LG. Bedroom size and social interaction of the psychiatric ward. Environ Behav 1970;2(3):255-70.

[52] Olson R. Design issues and Recommendations for an SR: the residents' perspectives. 1993.

[53] Urbanoski KA, Mulsant BH, Novotna G, Ehtesham S, Rush BR. Does the redesign of a psychiatric inpatient unit change the treatment process and outcomes? Psychiatr Serv 2013;64(8):804-7.
[54] Parrott FR. Real relationships : sociable interaction, material culture and imprisonment in a secure psychiatric unit. Cult Med Psychiatry 2010;34 (4):555-70.

[55] Kidd SA, Hasan N, Trapp J. Exploring the use of digital picture frames on schizophrenia inpatient wards. Psychiatr Serv 2015;66(3):330-.

[56] Polsky RH, Chance MA. Social interaction and the use of space on a ward of long term psychiatric patients. J Nerv Ment Dis 1980;168(9):550-5.

[57] Southard K, Jarrell A, Shattell MM, McCoy TP, Bartlett R, Judge CA. Enclosed versus open nursing stations in adult acute care psychiatric settings: Does the design affect the therapeutic Milieu? J Psychosoc Nurs Ment Health Serv 2012:50(5):28-34.

[58] Edwards J, Hults M. Open_ nursing stations on psychiatric wards. Perspect Psychiatr Care 1970;8(5):209-17.

[59] Wood VJ, Curtis SE, Gesler W, Spencer IH, Close HJ, Mason JM, et al. Spaces for smoking in a psychiatric hospital: social capital, resistance to control, and significance for_therapeutic landscapes. Soc Sci Med 2013;97:104-11.

[60] Smith S, Jones J. Use of a sensory room on an intensive care unit. J Psychosoc Nurs Ment Health Serv 2013;52(5):22-30.

[61] Van Der Schaaf PS, Dusseldorp E, Keuning FM, Janssen WA, Noothoorn EO. Impact of the physical environment of psychiatric wards on the use of seclusion. BJPsych 2013;202:142-9.

[62] Borckardt JJ, Madan A, Grubaugh AL, Danielson CK, Pelic CG, Hardesty SJ, et al. Systematic investigation of initiatives to reduce seclusion and restraint in a state psychiatric hospital. Psychiatr Serv 2011;62(5):477-83.

[63] Olver J, Love M, Daniel J, Norman T, Nicholls D. The impact of a changed environment on arousal levels of patients in a secure extended rehabilitation facility. Australas Psychiatry 2009;17:207-11.

[64] Jenkins O, Dye S, Foy C. A study of agitation, conflict and containment in association with change in ward physical environment. J Psychiatr Intensive Care 2014;1:1-9.

[65] Ulrich R, Bogren L, Gardiner SK, Lundin S. Psychiatric ward design can reduce aggressive behaviour. J Environ Psych 2018;57:53-66.

[66] Dressler T, Rohe T, Weber M, Strittmatter T, Fallgatter AJ. Effects of improved hospital architecture on coercive measures. World Psychiatry 2015;14(1):1056.

[67] Eggert JE, Kelly SP, Margiotta DT, Hegvik DK, Vaher KA, Kaya RT. Personenvironment interaction in a new secure forensic state psychiatric hospital. Behav Sci Law 2014;32(4):527-38.

[68] Dvoskin JA, Radomski SJ, Bennett C, Olin JA, Hawkins RL, Dotson LA, et al Architectural design of a secure forensic state psychiatric hospital. Behav Sci Law 2002;20(5):481-93.

[69] Nijman HLI, Rector G. Crowding and aggression on inpatient psychiatric wards. Psychiatr Serv 1999;50(6):830-1.

[70] Melin L, Gotestam K. The effects of rearranging ward routines on communication and eating behaviors of psychogeriatric patients. J Appl Behav Anal 1981;14(1):47-51.

[71] Peterson RF, Knapp TJ, Rosen JC, Pither BF. The effects of furniture arrangement on the behavior of geriatric patients. Behav Ther 1977;8(3):464-7.

[72] Shattell M, Bartlett R, Beres K, Southard K, Bell C, Judge CA, et al. How patients and nurses experience an open versus an enclosed nursing station on an inpatient psychiatric unit. J Am Psychiatr Nurses Assoc 2015;21(6):398-405.

[73] Parr H. Interpreting the _hidden social geographies_ of mental health: ethnographies of inclusion and exclusion in semi-institutional places. Health Place 2000;6(3):225-37.

[74] Chaudhury H, Mahmood A, Valente M. The use of single patient rooms versus multiple occupancy rooms in acute care environments. Coalition for Health Environments Research (CHER); 2005.

[75] Cowart T, Stoudemire A. Nursing staff development and facility design for medical-psychiatry units. Gen Hosp Psychiatry 1989;11(2):125-36.

[76] Secker J, Benson A, Balfe E, Lipsedge M, Robinson S, Walker J. Understanding the social context of violent and aggressive incidents on an inpatient unit. J Psychiatr Ment Health Nurs 2004;11(2):172-8.

[77] Robson D, Spaducci G, McNeill A, Stewart D, Craig TJK, Yates M, et al. Effect of implementation of a smoke-free policy on physical violence in a psychiatric inpatient setting: an interrupted time series analysis. Lancet Psychiatry 2017;4 (7):540-6.

[78] Marcheschi E, Tr Laike, Brunt D, Hansson L, Johansson M. Quality of life and place attachment among people with severe mental illness. J Environ Psychol 2015;41:145-54. 